\title{
A few good blades: An experimental test on the productivity of blade cores from the Casa Montero Early Neolithic flint mine (Madrid, Spain)
}

\author{
Nuria Castañeda \\ Université Paris 1 Panthéon-Sorbonne. UMR 8215-Trajectoires. Maison Archéologie \& Ethnologie, René- \\ Ginouvès. Allée de l’Université, 21 F-92023, Nanterre Cedex. France. Email: nuriacastanyeda@gmail.com
}

\begin{abstract}
:
Casa Montero flint mine (5337-5218 cal. BCE) was a production centre of blades that were probably distributed in a broad regional framework. Recent research on its lithic record has provided a method for the calculus of productivity for the blade cores based on the striking platform potential area. Taking into account several factors involved when discarding a blade for use it, the resulting ratio of useful blades per core was smaller than expected in contrast with the high number of cores abandoned in the site.

Shape, size and quality variability of raw material increased the difficulty of that approach. The blade reduction at Casa Montero was determined by the raw material variability within a core, the occurrence of raw material defects and knapping accidents and the presence of knappers with different skill levels. Most of the cores were discarded at different moments of the reduction process and only $40.5 \%$ reached the production of blades. The estimation results show a ratio of 3 to 20 blades per core. Nevertheless, an estimated amount of $\sim 251,000$ adequate blades were produced and potentially used in a time span of just a hundred years and in a context of very low population density as the Central Iberian Peninsula in Early Neolithic was.

In order to contrast the core productivity estimation method, an experimental test was carried out. This paper focuses on the results of this test, applying and adjusting the initial method.
\end{abstract}

Keywords: productivity; experimental test; blade production; Casa Montero flint mine; Early Neolithic

\section{Introduction}

Casa Montero (Madrid, Spain), dating to 5337-5218 cal. BCE (Díaz-del-Río \& Consuegra 2011: 226), is one of the most ancient flint mines in Europe together with Defensola (Italy) (Tarantini et al. 2011) and Treviño (Spain) (Tarriño et al. 2014). The mine was a production centre of blades that were probably distributed in a broad regional framework.

Productivity is a critical question regarding to prehistoric mining research in order to understand the economic and social implications of this phenomenon. Recent research on the

Published by the School of History, Classics and Archaeology, University of Edinburgh ISSN: 2055-0472. URL: http://journals.ed.ac.uk/lithicstudies/

This work is licensed under a Creative Commons Attribution 2.5 UK: Scotland License. 
lithic assemblage of Casa Montero has provided a calculation of the amount of blades that were produced at the mine and were selected for the transport and deferred use (Castañeda 2014: 323-338; Castañeda et al. 2015b: 484-485). The calculation was viable due to the technical homogeneity of the lithic assemblage.

This estimation was based on the data from the analysis of 75 blade cores and 986 blades. The calculation results showed a ratio of 3 to 20 blades per core and a total amount of $\sim 251,000$ adequate blades that were produced and potentially used for the whole mine, in a time span of just a hundred years (Castañeda 2014: 336-337; Castañeda et al. 2015b: 484485).

Even though the total amount of blades is quite important in a context of very low population density, as was the inner Iberian Peninsula at the Early Neolithic (Díaz-del-Río \& Consuegra 2011: 228), and comparing with the scarce lithic record of the contemporary sites: 3 blades at La Deseada (Rivas-Vaciamadrid, Madrid) (Díaz-del-Río \& Consuegra 1999: 254) and 64 blades at Phase I Cueva de la Vaquera (Torreiglesias, Segovia) (Estremera 2003: 139). Nevertheless, there seem to be only a few good blades produced per shaft, taking into account the effort on digging shafts up to ten meters deep (Capote et al. 2008: 129). Perhaps, this perception is based on the widespread assumption of blade production as the most efficient reduction method (e.g., Sheets \& Muto 1972; Renfrew \& Bahn 2000), and there is more literature on blade production experiments concerning pressure, indirect percussion and soft hammer percussion than stone hammer ones (e.g., Gallet 1998; Pelegrin 2000: Driscoll \& García-Rojas 2014). In addition, these kind of experiments on core efficiency are usually based on good quality homogeneous raw material and with a small sample of blades.

Previous experiments and theoretical approaches suggest that blade production has some constraints that other reduction methods do not. Initial shaping of the blade core is usually more complex and wasteful, blade production demands high quality raw materials and high knapping skill levels and it is exposed to a high risk of knapping accidents and fractures (e.g., Hayden et al. 1996; Bar-Yosef \& Kuhn 1999; Eren et al. 2008).

In order to contrast this perception of the results, an experiment test has been carried out.

\subsection{The production of blades at Casa Montero}

Blade blanks were the main production of the Casa Montero flint mine. Evidence supports the hypothesis that they were probably used as sickles (Castañeda et al. 2015b: 484) (Figure 1). Most parts of the reduction sequence took place at the mine: from nodule selection to blank production. Final blade products were selected for delayed use at different places, in order to improve transport efficiency (Castañeda \& Criado 2006: 231). While carrying shaped cores is taken into account, evidence supporting that this was a systematic behaviour is absent.

Due to the continental genesis of the silicification episodes and the ageing process, Casa Montero nodules usually show heterogeneity and several varieties of flint within the same nodule, with different degrees of ageing, from a opaline outer part (Opal CT), opaline chert (80\% quartz), and the inner part of recrystallized chert (95\% quartz) (Bustillo et al. 2009: 180). Each variety presents different properties for knapping and use. The operational sequence analysis shows that opaline flint and opal varieties were systematically discarded from the main production (Castañeda et al. 2008; Criado et al. 2010). This resulted in a considerable waste of raw material.

The blade reduction scheme carried out at Casa Montero was quite simple and homogeneous. The preferred support was a big flake blank, the crest preparation only occurred when needed, and the production was carried out, in a unipolar direction, from a unique striking platform and a unique blade front. The reduction sequence was organized in 
order to optimize the raw material and to predetermine the length of the final blade blanks (Castañeda et al. 2015b: 482-483). The election of the initial orientation of the blank was a critical strategy in Casa Montero blade production. It avoided the opaline parts of the core in the front and provided a predetermined length of $5 \mathrm{~cm}$. The blade production assemblage is composed of blades (more than 75\% of blades and cores), bladelets (between 10 to 20\%) and microblades (less than 7\%).
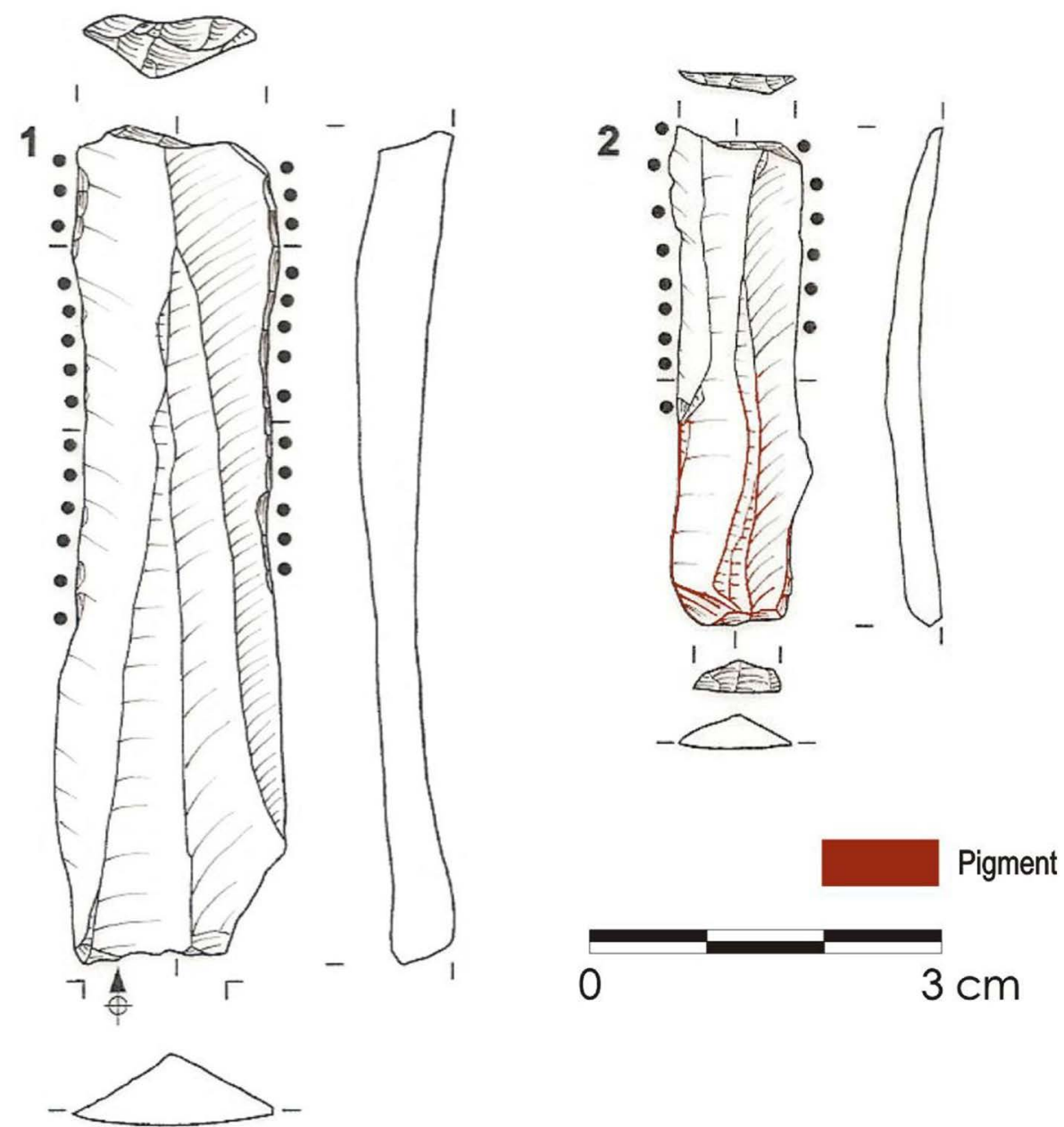

Figure 1. Blades used as sickles found at Casa Montero. (Drawings by Paco Fdez, Casa Montero Project.)

4565 (2,7\% of the studied assemblage) blades have been analysed. Taking into account that a selection of blades was carried out prior to transport them out of the mine, it is important to assume that Casa Montero blade assemblage is mostly composed of discarded by-products (Castañeda et al. 2015b: 483).

In general terms, in the process of blade exploitation of a core, resulting removals are different in quality, shape, size and goals. In consequence, blades were classified into three groups depending on the moment and purpose of its removal: initial blades (1), reconfiguration and cleaning blades (veins, accidents, etc.) (2) and production blades (3) (Figure 2). The latter group includes those blades that were intentionally produced but do not meet the criteria to be selected for transport and use. The two former groups represent $54.9 \%$ of the studied sample, while only the latter one is $45.1 \%$.

Production blades are the group closest in shape and size to those that were selected and used and, therefore, not preserved at the site. Typometric, technological and knapping stigmas analysis are based on this group of blades. 

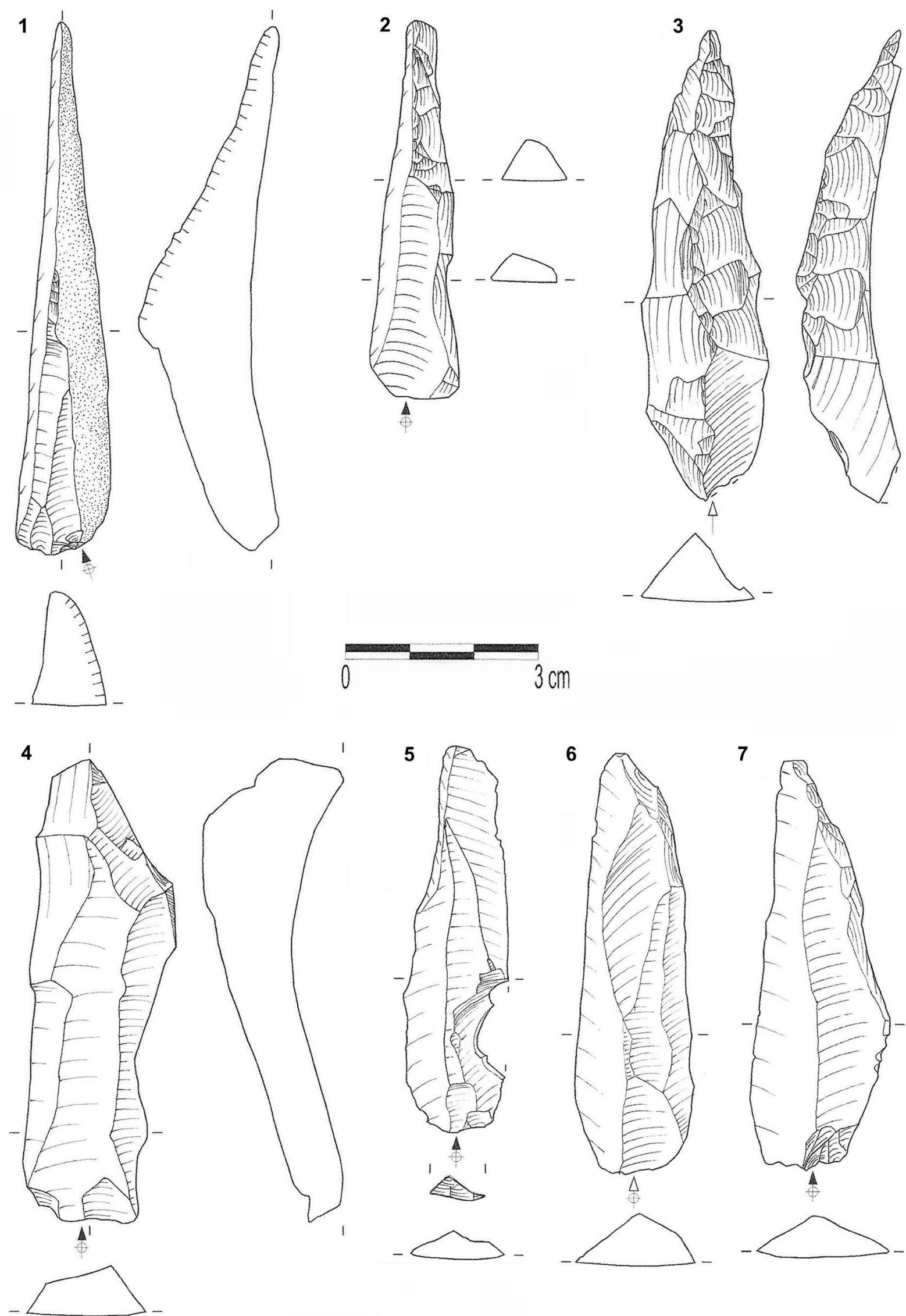

Figure 2. Types of blades from Casa Montero lithic assemblage. 1. Cortical initial blade; 2. Semi-crest; 3. Crest; 4. Cleaning blade (plunging); 5 to 7. Production discarded blades. (Drawings by Paco Fdez, Casa Montero Project.) 
The analysis of the dimensions is based on the sample of complete production blades ( $\mathrm{n}=$ 943; 780 blades and 163 bladelets). The mean size of the blades produced at Casa Montero is $50.48 \times 19.41 \times 5.9 \mathrm{~mm}$ (Table 1). The size together with the absence of bimodal distribution avoid to distinguish among blades, bladelets and microblades. It suggests that the general tendency of Casa Montero production was to obtain a small product including long bladelets and short and thick blades.

Table 1. descriptive statistic values for Casa Montero blade assemblage.

\begin{tabular}{|c|c|c|c|c|c|c|}
\hline & \multirow[b]{2}{*}{$\begin{array}{c}\text { Length } \\
(\mathrm{mm})\end{array}$} & \multirow[b]{2}{*}{$\begin{array}{l}\text { Width } \\
(\mathrm{mm})\end{array}$} & \multirow[b]{2}{*}{$\begin{array}{c}\text { Thickness } \\
(\mathrm{mm})\end{array}$} & \multirow{2}{*}{$\begin{array}{c}\text { Ratio } \\
\text { width : } \\
\text { thickness }\end{array}$} & \multicolumn{2}{|c|}{$\begin{array}{c}\text { Production blades } \\
\text { platform }\end{array}$} \\
\hline & & & & & width & thickness \\
\hline Mean & 50.48 & 19.41 & 5.9 & 0.11 & 12.65 & 5.04 \\
\hline Median & 48.49 & 18.33 & 5.56 & & 12.22 & 4.68 \\
\hline Mode & 37.72 & 18.77 & 6 & & & \\
\hline Standard deviation & 14.47 & 4.91 & 2.28 & 0.3 & 4.79 & 2.4 \\
\hline Variance & 181.57 & 24.1 & 5.18 & & 22.94 & 5.78 \\
\hline Kurtosis & 0.62 & 0.95 & 1.49 & & 0.67 & 0.71 \\
\hline Asymmetry & 0.81 & 1.02 & 1.02 & & 0.57 & 0.8 \\
\hline Minimum & 23.6 & 12.55 & 1.86 & & 0.78 & 0.58 \\
\hline Maximum & 104.49 & 39.28 & 18 & & 34.28 & 14.39 \\
\hline $\mathrm{N}$ & 780 & 780 & 780 & & 1022 & 986 \\
\hline Variation coefficient & 0.29 & 0.25 & 0.39 & 0.37 & 0.38 & 0.48 \\
\hline
\end{tabular}

These dimensions are very similar to those of Cueva de la Vaquera, Phase I (Segovia, Spain) that were probably coetaneous (Estremera 2003: 140-144), distant approximately 90 $\mathrm{km}$ to the north from Casa Montero.

From the point of view of technology, homogeneity is the main feature. Striking platforms of blades are unifaceted (71.11\%), prominent and diffuse bulb in almost same proportion (55.74\% diffuse) and mainly trapezoidal cross-section (66.41\%). According to some authors (e.g., Roussel et al. 2011:74; Driscoll \& García-Rojas 2014: 139) the distinction among the knapping techniques is difficult, especially when any isolated criteria is determining by itself (Castañeda 2014: 269-270). Even so, the studied sample from Casa Montero is wide enough to say that knapping attributes related to pressure are absent, those related to indirect percussion are weakly represented and the most probable hypotheses is the use of direct percussion (Castañeda 2014: 269-270). Following some authors criteria (e. j. Gallet 1998; Pelegrin 2000; Roussel et al. 2011) "soft stone” hammer meet 9 of 15 analysed attributes: mean length, width and thickness, platform preparation and dimensions, type of bulb, weak presence of lip (1.27\%), type of bulbar scar (41.99\% with origin in the impact point) and concentric fissures in the impact point (77.37\%) (Castañeda 2014: 275). The eventual use of other techniques is taking into account and is being developed in further experimental program with local raw material.

\section{Methods}

\subsection{Previous core efficiency estimation on Casa Montero blade production}

Carrying out a calculation of lithic productivity in a prehistoric context seems to be a difficult task a priori. On the one hand, there are multiple unpredictable, random or unknown variables that complicate it, as the initial shape and volume of a core, for example. On the 
other hand, the final estimation concerns, in this particular case, the missing part of the record: those blades that were selected for deferred use. These are called in this work "useful blades".

Prior to any consideration it is important to define the criteria used to discriminate a useful blade. Those criteria concern specially adjusting to predetermined dimensions (Table 1 ), and homogeneity in thickness in longitudinal section. The two sickle blades found at the site (Figure 1) or those from the Phase I of Cueva de la Vaquera (Gibaja et al. 2013) are the perfect models of useful blades. Those blades that did not meet these criteria were abandoned at the site and constitute the blade assemblage of the mine.

In order to calculate an estimation of useful blades produced per core at Casa Montero mining site, several variables have been taking into account: the initial shape and size of the striking platform of the cores after cresting and shaping prior to the production phase; the number of exhausted cores, the possibility of carrying out cleaning and repairing tasks and the number of produced and discarded blades. The estimation was made in two phases: the calculus of the produced blades per core and the calculus of the amount of cores per shaft.

To calculate how many blades were produced per core, the first parameter to be known must be which was the potential volume to be reduced. Previous works on blade core efficiency, took into account the initial volume of the nodule and all the waste originated in the phases of decortication and configuration (e.g., Eren et al. 2008: 953). In the present case study, the decision of excluding this part of the record from the calculation is justified due to several reasons. Firstly, the lithic remains of Casa Montero came from different reduction methods (Consuegra et al. 2004: 135-236; Castañeda et al. 2015a: 482) and only a small number of them can be reliably distinguished. Secondly, the high variability in reduction methods and blanks involves great differences in intensity of previous work between cores of the same initial volume. Finally, as a consequence of raw material genesis and ageing, the amount of opaline varieties within a core that were systematically discarded, cannot be taken into account, except when comparing the initial weight of raw material that were probably mined in each shaft with the weight of the final products selected to be used.

As a result, the starting point of the reduction of blades was the configured core. As the reduction advances, the number of removals and intensity in core configuration increases and the size of the core and the striking platform decreases (Marwick 2008: 1190).

The recurrence of the unipolar extraction of blades in volume causes the stability of the parts of the core after the configuration and before the beginning of producing blades. In general terms, the striking platform is always in the same place until the end of the reduction, except on reconfigured cores. Therefore, the striking platform potential area (SpPA) is the result of the sum of the exhausted core platform and all the blade platform areas. Consequently, if we know the area of the striking platform prior to the production of blades, we will be able to estimate how many blades were produced from a core.

In order to calculate the SpPA of Casa Montero cores, a method was designed in several steps: the selection of a suitable sample of cores; the calculus of the striking platform area (SpA) of recrystallized flint of each core and subtraction of SpA from the exhausted cores, that means the minimum surface of the platform necessary to manipulate the core (298.96 $\mathrm{mm}^{2}$ in the studied sample).

From the studied assemblage of 552 cores, the sample selected included 75 cores that met the following criteria: blade prismatic production, correct or expert execution, presence of recrystallized flint and abandonment phase prior to the production of blades. Taking into account that cores were abandoned at the mine in different moments of the reduction process due to several reasons, those which the work was stopped just prepared to start the production of blades, provide the initial platform size of the assemblage. The resulting SpPA was 
extremely variable to use the mean values. As a result, an interquartile range was used including $50 \%$ of the sample between 656.47 and $1754.81 \mathrm{~mm}^{2}$.

The SpPA was divided by the mean of the production platform area of blades (PAB) of Casa Montero (986 blades; $64.49 \mathrm{~mm}^{2}$ ). The result is the maximum number of blades (MNB) that can be knapped from a core: between 10 and 27 blades (Table 2).

Table 2. Calculation of the number of useful blades per core for Casa Montero assemblage. (986 blades, 64.49 $\mathrm{mm}^{2} \mathrm{PAB}$ ) Abbreviations: SpPA - striking platform potential area, PAB - platform area of blades, DB discarded blades.

\begin{tabular}{|c|c|c|c|c|}
\hline & $\begin{array}{c}\text { Striking platform } \\
\text { potential area }\left(\mathrm{mm}^{2}\right) \\
(\text { SpPA) }\end{array}$ & $\begin{array}{c}\text { Maximum number of } \\
\text { blades } \\
\text { (MNB=SpPA/PAB) }\end{array}$ & $\begin{array}{l}\text { Discarded } \\
\text { blades } \\
\text { (DB) }\end{array}$ & $\begin{array}{l}\text { Useful blades } \\
\text { (UB=MNB-DB) }\end{array}$ \\
\hline Minimum & 656.47 & 10.18 & \multirow{3}{*}{7.71} & 2.47 \\
\hline Median & 995.11 & 15.43 & & 7.72 \\
\hline Maximum & 1754.81 & 27.21 & & 19.5 \\
\hline
\end{tabular}

Some of these blades were produced but also abandoned at the site due to veins, knapping accidents or inappropriate size. The discarded blades per core calculation was based on the proportion of each type of blade at the site. Initial blades are usually 1 per core; technical solutions, repairing accidents and veins were 3.25 per core and discarded production blades were 3.46 per core. As a result, in each blade core from Casa Montero 7.7 by-products were generated. Consequently, only between two to 20 blades of each core were selected as useful blades.

To calculate the amount of useful blades per shaft it is necessary to know how many cores that were reduced by an expert knapper and were abandoned after blade production there were (Castañeda 2014: 332-335). 1861 cores were studied from 40 shafts, and only 241 cores meet these criteria, resulting in 24,100 for 4,000 shafts. The distribution of the sample and the difference in size of the shafts (from 1.5 to $10 \mathrm{~m}$ deep) prevent for using the descriptive statistic values of cores per shaft.

Then, it is being estimated the production for each core of the sample and the resulting amount of blades were divided by the number of shafts. The calculus of the production for each core has been made taking into account the discarding reasons (Castañeda 2014: 336). For those cores abandoned by veins and fracture (78 cores; $32.36 \%$ ) the minimum number of blades per core is been applied (78 x 2.47=193 blades). Exhausted cores (43; 17.85\%), and those with no obvious discarding reason $(47 ; 19.5 \%)$ are expected to produce the maximum of blades ( $43+47 \times 19.5=1,755$ blades). For the cores abandoned due to knapping accidents (73; $30.29 \%$ ) the median value was used ( $73 \times 7.72=564$ blades). This calculus results in 2513 blades for the 40 analysed shafts and 63 useful blades per shaft (Castañeda 2014: 335-337).

\subsection{Experimental test}

The experiment was carried out at the Experimental Archaeology Laboratory of the Universidad Autónoma de Madrid.

Taking into account that raw material was a critical variable in the study of core efficiency of Casa Montero, a big nodule from the site was the primary core for the experiment. The nodule presented an inner part with type 2 flint variety and a thin outer part of type 1 flint (Bustillo et al. 2009:183). This nodule was reduced into big flakes and fragments that were the blanks for the cores of the experiment. In this initial reduction a $30 \%$ of the initial volume was discarded due to the presence of big geodes in the centre of the nodule, and internal fissures produced by the strong impacts of breaking the nodule. 
The goal of the experiment was to contrast the expert execution efficiency on producing blades by "soft" stone hammer direct percussion. Three knappers participated in the experiment. The main knapper was Javier Baena, a well-known expert knapper, with more than 30 years of experience. The techniques and methods that he usually uses are bifacial reduction and Mousterian reduction methods, but he is also an expert on blade reduction using both direct and indirect percussion and pressure. The second knapper was Víctor Lamas, an advanced knapper, with 4 years of experience. He usually practices discoid and Levallois reduction method with stone hammer percussion. The third knapper was the author of this work, a medium experienced knapper, with discontinuity in practice. Her most practised methods and techniques have been stone hammer percussion on bifacial reduction and Levallois and prismatic methods. It is important to remark on each knapper's previous experience because modern knappers usually carry out different methods and techniques that were very distant in time. Some gestures are learned and remembered well, and it may become be a problem on reducing a different method they are not used to.

The knappers were asked to continue with the reduction until it the cores were exhausted. The reduction matched the features described for the Casa Montero blade reduction: unipolar blades, adaptation of the striking platform and knapping surface when needed.

Four hammers were used: one sandstone, one limestone and two quartz arenite.

The different blanks or cores were measured and weighted prior to the start of reduction, after configuration, and at the end of the reduction. The striking platform dimensions and shape were recorded during the same three phases, as well as recording the amount of cortex, geodes and fissures and the reason of abandonment. All of the resulting products were measured and weighed. Two precision scales were used: MOBBA Mod. XIC 85 (40 g-30 k $15 \mathrm{~g}$ prec.) and EKS (5 k max. $/ 1 \mathrm{~g})$.

Each reduction was identified by a number, the name of the knapper and the hammer. All the resulting products were collected except debris, and were separated by phases of the reduction sequence: configuration of the core, blades, accidents and core. Each reduction was refitted and every product was set in extraction order.

After the refitting each reduction was photographed and drawn.

Data was collected and managed with Excel 2016.

33 reductions were carried out, but most of them were abandoned in the initial shaping due to fractures, veins and small size. Only eight succeeded in production of blades and were suitable to be studied (Table 3), and 185 resulting products were analysed.

The following data for all the resulting products were recorded: type of product (type of blade or flake); platform features; platform dimensions; cross section; accidents; end shape and if it met the criteria to be useful or not.

A special interest was put on blade dimensions: maximum length; maximum width; mesial width and maximum thickness.

The estimation of Casa Montero core efficiency was based on the calculation of the blade platform area (PAB) mean. In general terms, the platform may be usually modified by abrasion or small removals on the edge, that results in decreasing of the platform area. Therefore, a new measure is proposed in order to adjust the calculation. The upside view of a blade usually includes a bigger area than the platform where width increases critically, being the end of platform adaptation and the maximum thickness of the bulb (Figure 3). Refitting shows that at this point all the blades and flakes fit perfectly. This point it is been called " $\mathrm{A}$ " point in this work and it has been measured in width and thickness on each blade and also the distance of this point from the impact point. In the studied sample, this point is located $5 \mathrm{~mm}$ from the impact point (n:181; mean 4.99; 95\% confidence; 2.47 std. deviation). These measures in "A" point have been used to adjust the productivity calculus, and will be included in future experiments on knapping techniques. 
Table 3. Data from the experimental reductions suitable for the study.

\begin{tabular}{|c|c|c|c|c|c|c|c|}
\hline $\begin{array}{l}\text { Core } \\
\text { ID }\end{array}$ & Skill & Hammer & $\begin{array}{c}\text { Reason of } \\
\text { abandonment }\end{array}$ & 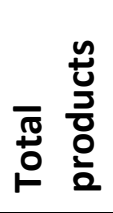 & 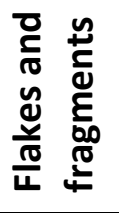 & 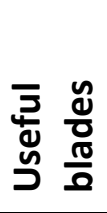 & $\begin{array}{l}\text { Reduction } \\
\text { scheme }\end{array}$ \\
\hline 1 & expert & sandstone & plunging & 22 & 6 & 2 & \multirow{6}{*}{$\begin{array}{c}\text { Unique platform } \\
\text { and front }\end{array}$} \\
\hline 3 & middle & $\begin{array}{l}\text { quartz } \\
\text { arenite }\end{array}$ & hinges & 19 & 3 & 7 & \\
\hline 5 & expert & sandstone & small size & 30 & 4 & 4 & \\
\hline 11 & expert & $\begin{array}{l}\text { quartz } \\
\text { arenite }\end{array}$ & hinges & 27 & 5 & 5 & \\
\hline 19 & expert & sandstone & hinges & 20 & 4 & 3 & \\
\hline 21 & expert & sandstone & $\begin{array}{l}\text { hinges \& } \\
\text { geode }\end{array}$ & 7 & 0 & 1 & \\
\hline 22 & expert & $\begin{array}{c}\text { sandstone \& } \\
\text { quartz } \\
\text { arenite }\end{array}$ & plunging & 51 & 24 & 12 & $\begin{array}{c}\text { Unique platform } \\
\text { and two opposite } \\
\text { fronts }\end{array}$ \\
\hline 29 & middle & sandstone & small size & 9 & 2 & 1 & $\begin{array}{c}\text { Unique platform } \\
\text { and front }\end{array}$ \\
\hline Total & & & & 185 & 48 & 35 & \\
\hline
\end{tabular}

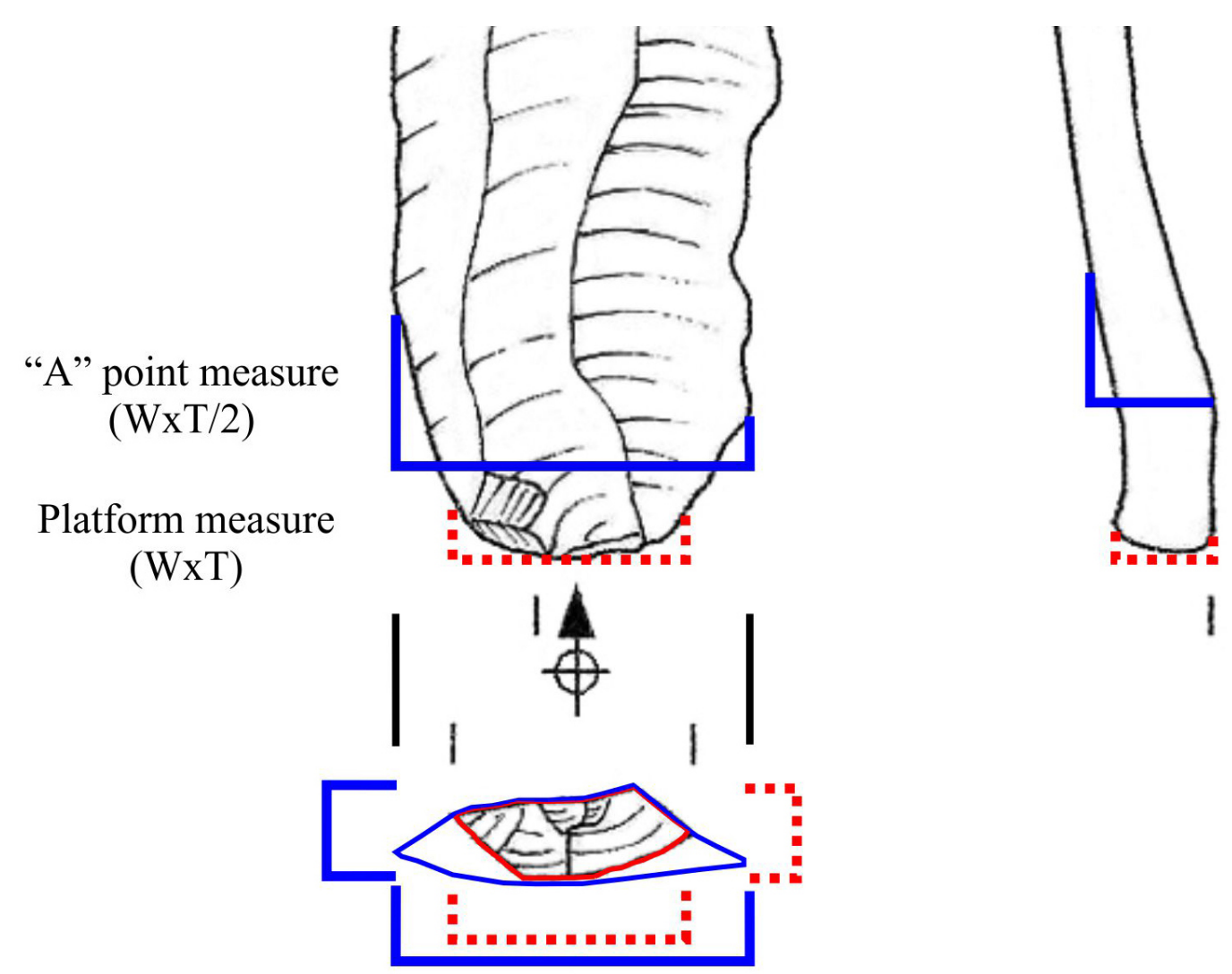

Figure 3. Different measure points of a blade used in this work. (Drawings by Paco Fdez, Dibujantes de Arqueología.) 


\section{Results and discussion}

From the 185 resulting products of the experiment, 142 were blades, only 117 of them conserve the platform and 74 were complete. Both experimental and archaeological samples are difficult to compare due to the difference in the sample size, being the mean and median of the blade and platform dimensions smaller in the experimental sample than in the archaeological assemblage. In spite of this, dimensions of both samples are comparable due to the results of the Two Sample Kolmogorov-Smirnov test (Table 4).

Table 4. Descriptive statistics and KS test values for width and thickness of experimental and archaeological blade production platforms.

\begin{tabular}{|c|c|c|c|c|}
\hline & \multicolumn{2}{|c|}{ Platform width } & \multicolumn{2}{|c|}{ Platform thickness } \\
\hline & Experimental & Casa Montero & Experimental & Casa Montero \\
\hline Mean & 7.34 & 11.99 & 2.37 & 4.69 \\
\hline Standard error & 0.50 & 0.14 & 0.20 & 0.07 \\
\hline Median & 7 & 11.39 & 2 & 4.26 \\
\hline Mode & 5 & 12 & 1 & 4 \\
\hline Standard deviation & 3.97 & 4.86 & 1.61 & 2.42 \\
\hline Minimum & 1.5 & 0.78 & 0.5 & 0.31 \\
\hline Maximum & 25 & 34.28 & 8 & 14.39 \\
\hline $\mathrm{N}$ & 62 & 1170 & 62 & 1170 \\
\hline Confidence level (95.0\%) & 1.01 & 0.28 & 0.41 & 0.14 \\
\hline Two samples KS test (d/p) & \multicolumn{2}{|c|}{$0.31 / 2.448^{-05}$} & \multicolumn{2}{|c|}{$0.32 / 1.373^{-05}$} \\
\hline
\end{tabular}

The range of useful blades obtained per core in the experiment goes from only one to 12 , that is even less than the amount of blades estimated for the archaeological sample (from 2.47-19.5). There are some constraints to compare these results: the difference in the size of the sample and the scarce experience of the knappers on blade production with soft stone hammer. Nevertheless, these results are similar to the estimation for the archaeological sample and the knapping method reveals as unproductive.

With respect to the proportions of types of blades in the two samples, they are apparently very different, but it is important to take into account that there is a group of removals that can be recorded on the experimental sample that remains unknown in the archaeological one: those flakes and fragments generated in the blade production phase that are impossible to differentiate from those of the configuration phase, without complete refitting (Figure 4). On comparing the two samples it is important to assume that this group of flakes and fragments is included in the estimation of useful blades of Casa Montero (38.49\%). Therefore, we can compare this estimated percentage with the sum of useful blades and flakes or fragments of the experimental sample (45.48\%). Consequently, this is one of the limits of the estimation method and any calculi of production of blades will result bigger. With a broader experimental program providing consistent data it will be hypothetically possible to calculate the relative frequency of the occurrence of flakes and fragments within this type of reduction.

This was one of the reasons to carry out a method to contrast and adjust the initial method and estimation. The first phase of contrast consists in applying the estimation carried out on Casa Montero assemblage to the experimental sample and comparing the total amount of products estimated per core with the real ones. The second phase of contrast relates to the estimation method of the unknown fraction of the lithic record: flakes and fragments generated in the production phase and useful blades. 


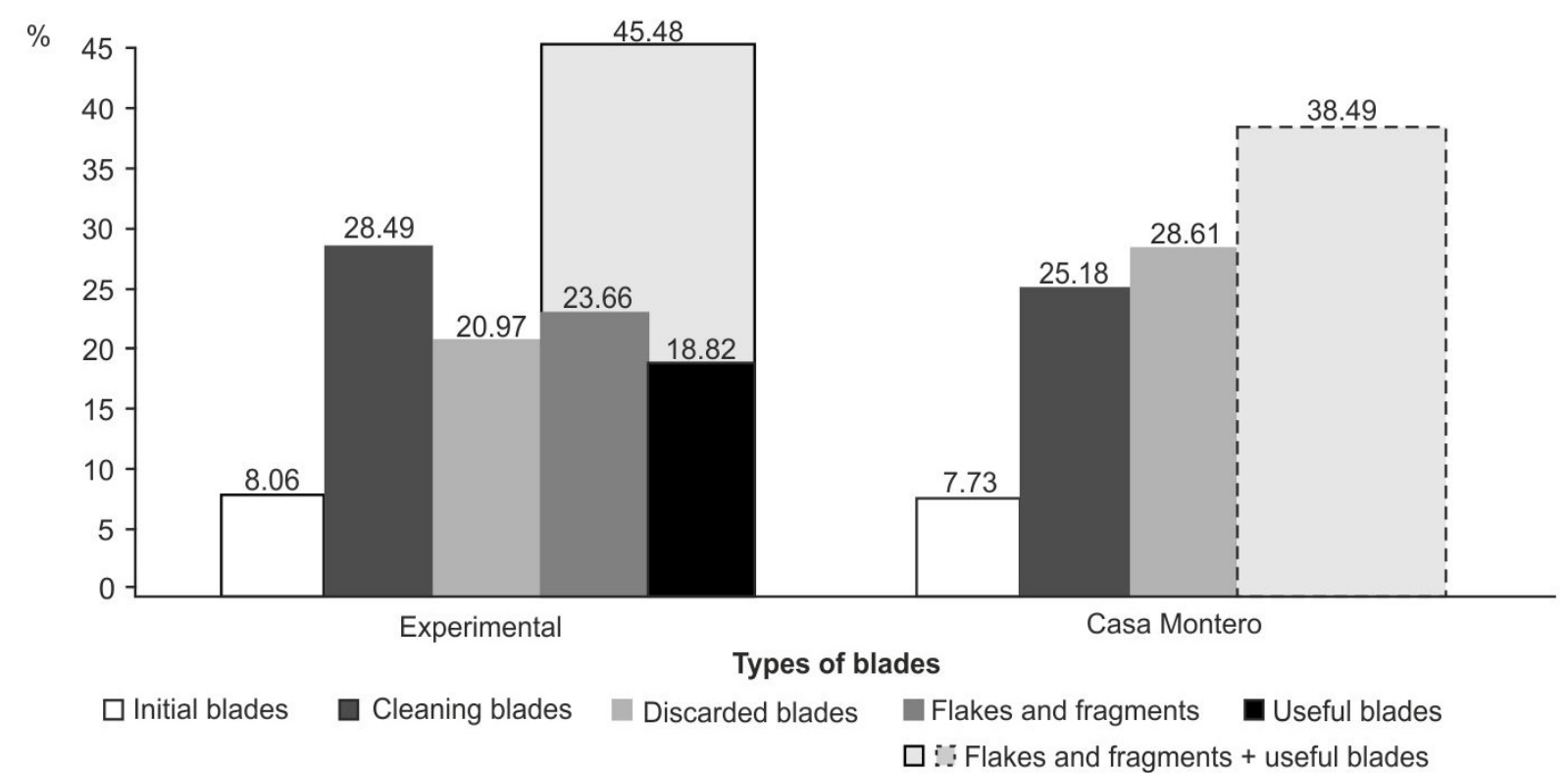

Figure 4. Percentages of the types of products obtained by experimental replication and from the archaeological sample. The proportional calculus of the Casa Montero sample has been made by assuming the final estimation of 64 blades per shaft of 34 analysed shafts.

As it can be seen on Table 5, the estimated number of total products based on the platform area of blades (PAB) is bigger than the estimation based on "A" point area (APA) and the number of real total products. The core number 22 has provided outlier results. A total amount of 173.19 products were hypothetically produced (case n. 22 was not included) with PAB estimation method, and 134 with APA method, this latter result is closer to the real amount of total products obtained. Comparing the results with each core independently, the estimation made by " $A$ ” point area is very similar to the real data.

Table 5. Application of the estimation method of Casa Montero to the experimental sample.

\begin{tabular}{|c|c|c|c|c|c|c|c|}
\hline Core ID & SpPA $\left(\mathrm{mm}^{2}\right)$ & $\begin{array}{c}\text { Estimation of } \\
\text { total } \\
\text { products by } \\
\text { platform } \\
\text { area (PAB) }\end{array}$ & $\begin{array}{l}\text { Estimation of } \\
\text { total } \\
\text { products by } \\
\text { "A" point } \\
\text { area (APA) }\end{array}$ & $\begin{array}{l}\text { Real total } \\
\text { products }\end{array}$ & $\begin{array}{l}\text { Estimation of } \\
\text { useful blades } \\
\text { and flakes } \\
\text { (a) }\end{array}$ & $\begin{array}{c}\text { Real } \\
\text { flakes \& } \\
\text { useful } \\
\text { blades } \\
\text { (b) }\end{array}$ & $\begin{array}{c}\text { Difference } \\
(a-b)\end{array}$ \\
\hline 1 & 642.5 & 23.87 & 19.21 & 22 & 12.07 & 8 & 4.07 \\
\hline 3 & 578 & 21.47 & 17.28 & 19 & 10.14 & 10 & 0.14 \\
\hline 5 & 717 & 26.63 & 21.44 & 30 & 14.3 & 8 & 6.3 \\
\hline 11 & 1137 & 42.24 & 34 & 27 & 26.86 & 10 & 16.86 \\
\hline 19 & 837.75 & 31.12 & 25.05 & 20 & 17.91 & 7 & 10.91 \\
\hline 21 & 292.5 & 10.87 & 8.75 & 7 & 1.61 & 1 & 0.61 \\
\hline 22 & 4887.25 & 181.55 & 146.15 & 51 & 131.87 & 36 & 95.87 \\
\hline 29 & 457.5 & 16.99 & 13.68 & 9 & 6.54 & 3 & 3.54 \\
\hline Total & & 354.74 & 285.57 & 185 & 221.31 & 83 & 138.31 \\
\hline Without & core $\mathrm{n} .22$ & 173.19 & 134 & 139.42 & 89.44 & 47 & 42.44 \\
\hline
\end{tabular}

On estimating the useful blades per core, the problem is that it is a number that is unknown for the archaeological sample, while it is not in the experimental one. Therefore, it is important to take into account that the 107 discarded blades of the experimental sample (57.52\%) would be the $100 \%$ of an archaeological sample, because the amount of useful 
blades that were transported outside the site and the amount of flakes and fragments generated on the production phase of blade reduction are unknown. If for each core there is at least one initial blade (two initial blades for the exceptional case of core number 22) it corresponds to $14.01 \%$ of the known sample, and then, the amount of discarded blades per core is 7.14 , (14.28 for the number 22).

As a consequence, the results of applying the estimation method to the experimental sample is approximately double than the real amount of flakes and useful blades (Table 5).

The case of core number 22 is different to the rest of the cores. Regarding to the refitting scheme, it is evident that the estimation did not took into account the different size of the different types of by-products (Figure $5 \mathrm{C}$-D). This aspect must be into account in future corrections of the method.

In light of the experiment and the results, the initial method for the calculation of the core effectiveness for unipolar blade reduction with soft stone hammer percussion seems to be good but must be improved including the " $A$ " point measurement and the variability in size between the different types of blades.

This experiment is preliminary and a larger sample of reduced cores is needed in order to reinforce the results. Therefore, it is still impossible to recalculate the number of total useful blades that were produced at Casa Montero, at least for now, but everything appears to indicate that it will decrease. It will imply a higher difference between the effort of digging a shaft and the final useful amount of flint obtained.

It is also revealed that raw material heterogeneity is critical to productivity and an abundant source could become scarce in good raw material.

The election of the reduction technique may be an important factor also. Although it is very difficult to identify the kind of hammer used in Casa Montero, most of the attributes analysed suggests that the most probable used technique was soft stone direct percussion. Nevertheless, it is also possible that indirect percussion could be used.

A new experimental approach will improve the size of the sample, the skill of the knappers within the reduction technique, and will include other techniques in order to adjust and contrast the initial hypothesis. The inclusion of this variable will change the results of the productivity estimation and its implications.

\section{Conclusion}

Research on technology related to mining and production activities requires to take into account productivity to appraise these tasks in socio-economic terms. Recent research on the Casa Montero Early Neolithic flint mine has provided an estimate of the amount of blades that were produced at the mine and were selected for the transport and deferred use. Even though the resulting estimated total amount of $\sim 251,000$ blades is quite important in a context of very low density population, a ratio of three to 20 useful blades per core seemed to be very low.

The goal of this work was to contrast the expert execution efficiency on producing blades by "soft" stone hammer direct percussion and the estimation method used in Casa Montero. 33 reductions were carried out, but only 8 were suitable to be studied, and 186 resulting products were analysed. 


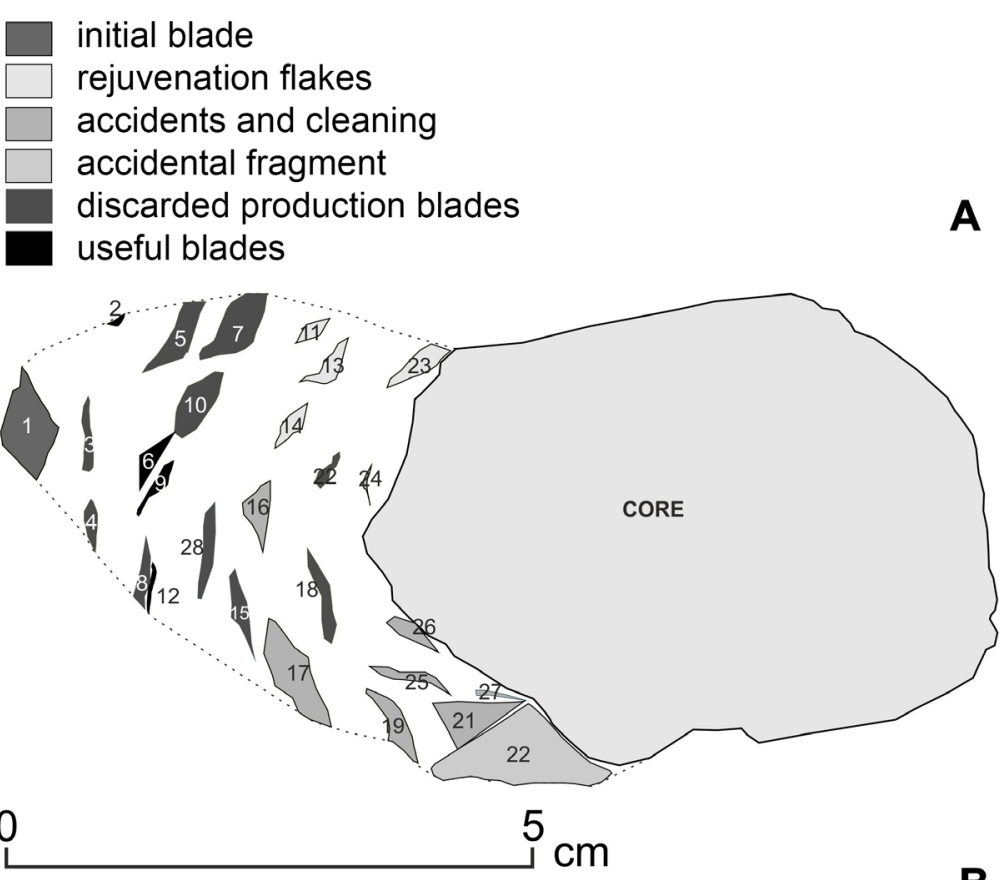

rejuvenation flakes

accidents and cleaning

rejuvenation blade

discarded production blades

A

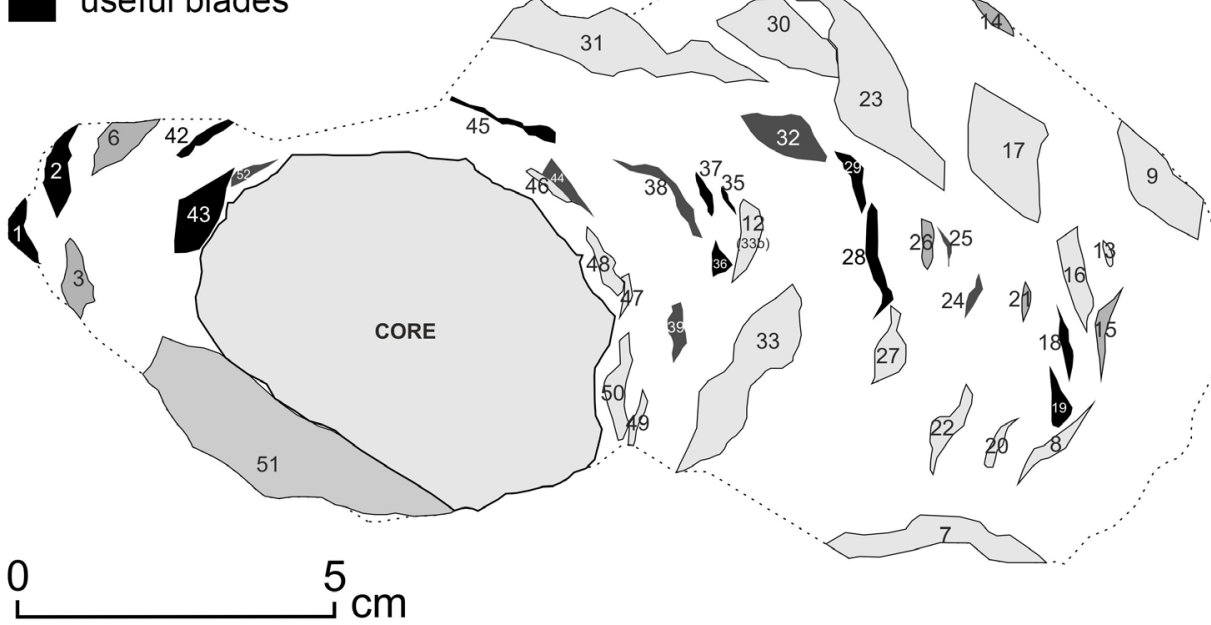

B

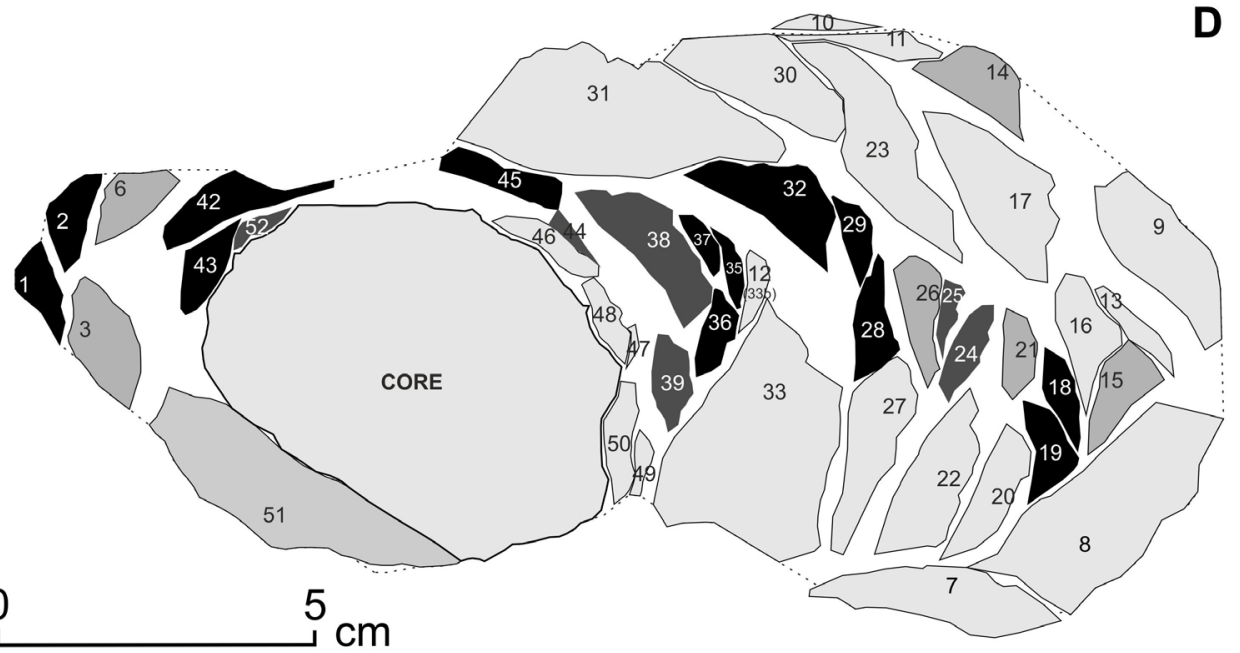
0 $5 \mathrm{~cm}$ $5 \mathrm{~cm}$

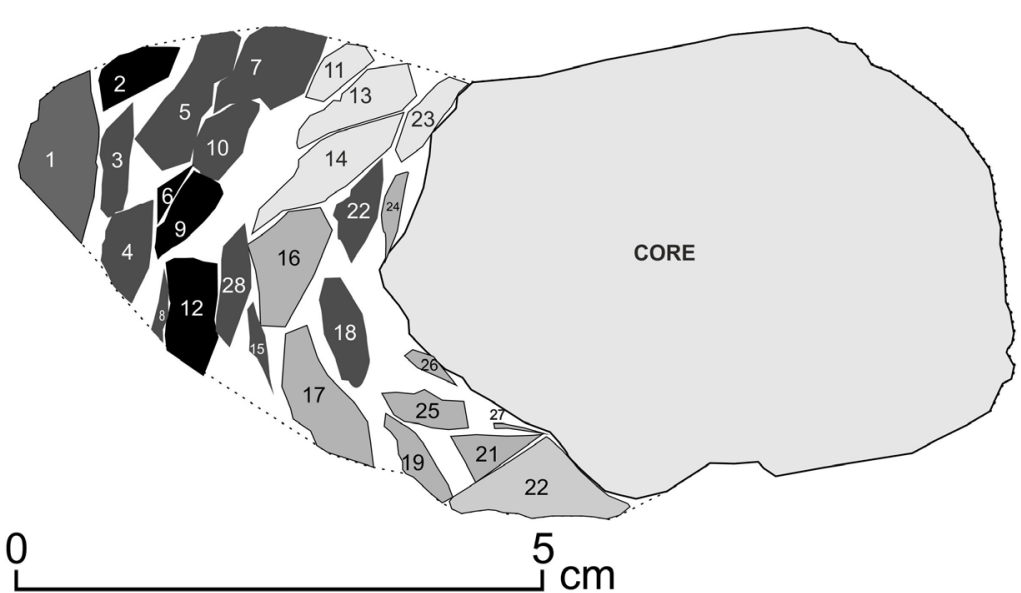

\section{0}

Figure 5. Upside view of the striking platform and all refitted experimental reduction products: A-B. Number 5; C-D. Number 22. A-C. Platform area; B-D. “A” point area. 
The results reveal that there are some difficulties on the initial estimation approach that were not taken into account. The first one is that the estimation of Casa Montero core efficiency was based on the calculation of the blade platform area mean. Refitting showed that there is a loss of material that this measure does not include. A new method of measurement, called "A" point measure, is proposed in order to adjust the calculation. At this point the cross section area of blades is bigger than the platform area and fits perfectly covering most of the initial striking platform of the core.

Using the " $A$ " point measurement, the estimation of the total amount of products is closer to the real data. The method improved including " $\mathrm{A}$ " point measure seems to be accurate, but a new experiment with a bigger sample of reduced cores is needed in order to reinforce the results.

The second problem is that the initial calculation of blade core efficiency was based on the platform area mean of the blades originated in the production phase. This experiment reveals that it is important to use the "A" point area mean of each kind of by-product and the relative frequency in which they occur.

The third and main difficulty of the estimation method is that those flakes that were generated in the production phase of the reduction cannot be distinguished in the archaeological record. As a result, the estimation of the unknown part of the assemblage, includes not only the transported blades, but also these flakes. Both second and third problems will be probably solved with a broader experiment.

Nevertheless, the method is a new contribution that can be applied to any direct percussion based blade assemblage and can be improved to other techniques.

Therefore, it is still impossible to recalculate the number of total useful blades that were produced at Casa Montero, at least for now, but all indicates that it will decrease. It will imply a higher difference between the effort of digging a shaft and the final useful amount of flint obtained. If the final amount of useful blades is bigger than the initial estimation, the problem will focus on the circulation and use of these blades in a very scarcely populated area. If the results are smaller, they will bring into question the idea of productivity of the mine, in economic terms.

\section{Acknowledgements}

This research was undertaken while the author held a Research in Paris Post-Doctoral Fellowship for Foreign Researchers funded by the Paris Council at the UMR 8215 Trajectoires de la sedetarisation à l'etat and the University Paris I-Panthéon Sorbonne.

This work has been carried out as part of the agreement between the Consejería de Cultura y Deportes de la Comunidad de Madrid, the CSIC, and Autopistas Madrid Sur Concesionaria Española, S.A. for the research, preservation and diffusion of the Casa Montero archaeological site. The experiment was carried out at the Experimental Archaeology Laboratory, Department of Prehistory and Archaeology, Autonomous University of Madrid. The author would like to thank Javier Baena and Víctor Lamas for carrying out the reductions; Susana Consuegra and Pedro Díaz-del-Río for the access to raw material, and Francisco Javier Fernández (Paco-Fdez-Dibujantes de Arqueología) for the drawings.

\section{References}

Bar-Yosef, O. \& Kuhn, S.L. 1999, The big deal about blades: Laminar technologies and human evolution. American Anthropologist, 101: 322-338.

doi:10.1525/aa.1999.101.2.322 
Bustillo, M. A., Castañeda, N., Capote, M., Consuegra, S., Criado, C., Díaz-Del-Río, P., Orozco, T., Pérez-Jiménez, J.L. \& Terradas, X. 2009, Is The Macroscopic Classification of Flint Useful? A Petroarchaeological Analysis and Characterization of Flint Raw Materials from The Iberian Neolithic Mine of Casa Montero. Archaeometry, 51(2): 175196. doi:10.1111/j.1475-4754.2008.00403.x

Capote, M., Castañeda, N., Consuegra, S., Criado, C. \& Díaz-Del-Río, P. 2008, Flint mining in Early Neolithic Iberia: A preliminary report on 'Casa Montero' (Madrid, Spain), In: Flint mining in prehistoric Europe: Interpreting the archaeological records. Papers presented at the 12th Annual Conference of the European Association of Archaeologists, Cracow (Poland) (Allard, P., Bostyn, F., Giligny, F. \& Lech, J., Eds.), British Archaeological Reports International Series Vol. 1891. Archaeopress, Oxford: p. 123-137.

Castañeda, N. \& Criado, C. 2006, La industria lítica de Casa Montero (Vicálvaro, Madrid); resultados preliminares. In: Do Epipaleolítico ao Calcolítico na Península Ibérica. Actas do IV Congresso de Arqueología Peninsular. Faro, 14 a 19 setembro de 2004. Universidade do Algarve, Faro (Portugal) (Ferreira Bicho, N. \& Verísssimo, H., Eds.), Universidade do Algarve, Departamento de História, Arqueologia e Património, Centro de Estudos de Património, Faro: p. 229-234. (in Spanish) (Lithic industry from Casa Montero (Vicálvaro, Madrid); preliminar results)

Castañeda, N. 2014, El trabajo del sílex. La mina del Neolítico antiguo de Casa Montero (Madrid) y su Sistema Técnico. PhD. thesis no. 1887/18370 at the Faculty of Philosophy, Universidad Autónoma de Madrid, Madrid, 626 p. (in Spanish) (Flint working. Early Neolithic mine of Casa Montero and its Technical System) URL: http://hdl.handle.net/10486/661865

Castañeda, N., Capote, M., Criado, C., Consuegra, S., Díaz-Del-Río, P., Terradas, X. \& Orozco, T. 2008, Las cadenas operativas líticas de la mina de sílex de Casa Montero (Madrid), In: Actas del IV Congreso Neolítico Peninsular, Vol. 2 (Hernández Pérez, M.S, Soler Díaz, J.A., López Padilla, J.A.), Museo Arqueológico de Alicante (MARQ), Alicante: p. 231-234. (in Spanish) (The operative sequences from Casa Montero flint mine (Madrid))

Castañeda, N., Casas, C., Criado, C. \& Nieto, A. 2015a, Las Cadenas Operativas de fabricación de instrumentos retocados en el conjunto lítico de Casa Montero (Madrid), In: 5. ${ }^{\circ}$ Congresso do Neolítico Peninsular. Atas. Lisboa 6-8 abril 2011 (Gonçalves, V. S., Diniz, M. \& Sousa, A. C., Eds.), UNIARQ (Centro de Arqueologia da Universidade de Lisboa), Lisbon: p. 474-479. (in Spanish) (Operative chaines for making retouched tools from the lithic assemblage of Casa Montero (Madrid))

Castañeda, N., Criado, C., Nieto, A. \& Casas, C. 2015b, La producción laminar de Casa Montero (Madrid), In: 5. ${ }^{\circ}$ Congresso do Neolítico Peninsular. Atas. Lisboa 6-8 abril 2011 (Gonçalves, V. S., Diniz, M. \& Sousa, A. C., Eds.), UNIARQ (Centro de Arqueologia da Universidade de Lisboa), Lisbon: p. 480-484. (in Spanish) (Blade production from Casa Montero (Madrid))

Consuegra S., Gallego, M. M. \& Castañeda, N. 2004, Minería neolítica en Casa Montero (Vicálvaro, Madrid), Trabajos de Prehistoria, 61(2): 121-140. (in Spanish) (Neolithic mining at Casa Montero (Vicálvaro, Madrid)) doi:10.3989/tp.2004.v61.i2.47 
Criado, C., Castañeda, N., Capote, M., Bustillo, M. Á., Pérez-Jiménez, J. L., Consuegra, S., Díaz-del-Río, P., Orozco, T. \& Terradas, X. 2010, El ‘sílex Casa Montero’: Estudio y caracterización, In: Minerales y Rocas en las sociedades de la Prehistoria (DomínguezBella, S., Ramos, J., Gutiérrez, J.M. \& Pérez, M., Eds.), Grupo de Investigación HUM440, Universidad de Cádiz, Cádiz: p. 187-198. (in Spanish) (The 'Casa Montero Flint': Study and characterization)

Díaz- del-Río, P. \& Consuegra, S. 1999, Primeras evidencias de estructuras de habitación y almacenaje neolíticas en el entorno de la Campiña madrileña: El yacimiento de" La Deseada"(Rivas-Vaciamadrid, Madrid), In: II Congrés del Neolític a la Península Ibérica, SAGVNTVM Vol. Extra 2. University of Valencia, Valencia: p. 251-257. (in Spanish) (First evidences of hábitat and storage neolithic structures in Madrid countryside: The site of La Deseada (Rivas-Vaciamadrid, Madrid)) URL: http://hdl.handle.net/10261/15367

Díaz-del-Río, P. \& Consuegra, S. 2011, Time for action. The chronology of mining events at Casa Montero (Madrid, Spain), In: Proceedings of the 2nd International Conference of the UISPP Commission on Flint Mining in Pre- and Protohistoric Times. (Madrid, 1417 October 2009) (Capote, M., Consuegra, S., Díaz-del-Río, P. \& Terradas, X., Eds.), British Archaeological Reports International Series Vol. 2260, Archaeopress, Oxford: p. 221-229.

Driscoll, K. \& García-Rojas, M. 2014, Their lips are sealed: Identifying hard stone, soft stone, and antler hammer direct percussion in Palaeolithic prismatic blade production, Journal of Archaeological Science, 47: 134-141. doi:10.1016/j.jas.2014.04.008

Eren, M.I., Greenspan, A. \& Sampson, C.G. 2008, Are Upper Paleolithic blade cores more productive than Middle Paleolithic discoidal cores? A replication experiment, Journal of Human Evolution, 55: 952-961. doi:10.1016/j.jhevol.2008.07.009

Estremera, M. S. 2003, Primeros agricultores y ganaderos en la Meseta Norte: El Neolítico de la Cueva de La Vaquera (Torreiglesias, Segovia), Memorias de Arqueología en Castilla y León Vol. 11, Junta de Castilla y León, Consejería de Educación y Cultura, Zamora, 320 p. (in Spanish) (First farmers in North Meseta: The Neolithic at Cueva de la Vaquera (Torreiglesias, Segovia))

Gallet, M. 1998, Pour une technologie des débitages laminaires préhistoriques, Dossier de documentation archéologique Vol. 19, Centre National de la Recherche Scientifique (CNRS) Éditions, Paris, 180 p. (in French) (For a technology of prehistoric blade knapping)

Gibaja, J. F., Estremera, M. S., Ibáñez, J. J., \& Perales, U. 2013, Instrumentos líticos tallados del asentamiento neolítico de La Vaquera (Segovia) empleados en actividades agrícolas, Zephyrvs, 70: 33-47. (in Spanish) (Knapped lithic tools from La Vaquera (Segovia) neolithic settlement used in farming activities)

URL: http://revistas.usal.es/index.php/0514-7336/article/view/9326

Hayden, B., Franco, N. \& Spafford, J. 1996, Evaluating lithic strategies and design criteria, In: Stone Tools: Theoretical Insights into Human Prehistory (Odell, G.H., Ed.), Plenum Press, New York: p. 9-45.

Marwick, B. 2008, What attributes are important for the measurement of assemblage reduction intensity? Results from an experimental stone artefact assemblage with relevance to the Hoabinhian of mainland Southeast Asia, Journal of Archaeological Science, 35: 1189-1200. doi:10.1016/j.jas.2007.08.007 
Pelegrin, J. 2000, Les techniques de débitage laminaire au Tardiglaciaire: Critères de diagnose et quelques réflexions. In: L'Europe Centrale et Septentrionale au Tardiglaciaire. Confrontation des modèles régionaux: Actes de la table-ronde internationale de Nemours 14-15-16 mai 1997 (Valentin, B., Bodu, P. \& Christensen, M., Eds.), Mémoires de le Musée de Préhistoire de l'Île-de-France Vol. 7, Association pour la Promotion de la Recherche Archéologique en Ile de France (APRAIF), Nemours: p. 73-86. (in French) (Blade knapping techniques in the Late Glacial period: Criteria for diagnosis and some reflections)

Renfrew, C. \& Bahn, P. 2000, Archaeology: Theories, Methods, and Practice, Thames and Hudson, New York, 640 p.

Roussel, M., Bourguignon, L. \& Soressi, M. 2011, Las 'bolas' o ‘boules de caliza' musterienses: ¿Percutores?, el ejemplo del 'fasonado' de las raederas bifaciales de Quina de Chez-Pinaud (Jonzac, Francia), In: La investigación experimental aplicada a la Arqueología (Morgado, A., Baena, J. \& García, D., Eds.), Departamento de Prehistoria y Arqueología de la Universidad de Granada, Granada: p. 69-76. (in Spanish) (The Mousterian "balls" or "limestone boules": Hammers?, The façonnage of Quina bifacial scrapers from Chez-Pinaud (Jonzac, France))

Sheets, P.D. \& Muto, G.R. 1972, Pressure blades and total cutting edge: An experiment in lithic technology, Science, 175: 632-634. doi:10.1126/science.175.4022.632

Tarantini, M., Galiberti, A. \& Mazzarocchi, F., 2011, Prehistoric Flint Mines of the Gargano: An Overview, In: Proceedings of the 2nd International Conference of the UISPP Commission on Flint Mining in Pre- and Protohistoric Times. (Madrid, 14-17 October 2009) (Capote, M., Consuegra, S., Díaz-del-Río, P. \& Terradas, X., Eds.), British Archaeological Reports International Series Vol. 2260, Archaeopress, Oxford: p. 253-264

Tarriño, A., Elorrieta, I., García-Rojas, M., Orue, Í. \& Sánchez, A. 2014, Neolithic flint mines of Treviño (Basque-Cantabrian Basin, Western Pyrenees, Spain), Journal of Lithic Studies, 1(2): 129-147. doi:10.2218/jls.v1i2.1098 